\title{
Developing Trust Towards Educational Institutions in Indonesia
}

\author{
Eddy Setyanto ${ }^{1}$, Hardianto ${ }^{2}$ \\ \{eddy.setyanto@gmail.com ${ }^{1}$, hardiantocally@gmail.com $\left.{ }^{2}\right\}$ \\ Universitas Indraprasta PGRI, Indonesia ${ }^{1}$ \\ Universitas Pasir Pengaraian, Indonesia ${ }^{2}$
}

\begin{abstract}
A trust towards educational institution is absolutely needed to guarantee its existence. Any educational institution without trust can hardly get new students. The methodology of this article involved literature studies. Problems in research are were evident from the phenomena in the field. The discussion uses descriptive analysis approach and data collection was by analyzing comparisons of previous research results and related theories as well as other relevant sources. Developing a trust in schools can be facilitated by such aspects as integrity, competence, consistency, loyalty, and openness obtained from either internal or external parties. Trust can also be achieved by a powerful leadership, a conducive organization setting, organization culture, communication, personality, a rule obedience and product description or graduation profile.
\end{abstract}

Keywords: Developing, trust, education, school lease list your keywords in this section.

\section{Introduction}

A school is an institution particularly designed to be a learning organization. The existence of educational institution is significantly needed to achieve Indonesian's goals. Indisputably, the preservation of culture as well as the noble value of the nation can be created through education. In Indonesia, formal education begins with elementary schoools to higher learning institutions.

The educational institutions in Indonesia are not only managed by government, that is, 'State' school, but also controlled by the society. The existence of private school supports government in educational equity program meant to promote learning. A good educational institution must gain the trust of the society.

Nowadays, the state schools tend to be trusted more than the private ones, even though some of them still promote society's interest. The community's trust towards educational institutions must always be on an upward trend. The total number of schools in Indonesia at the present amounts to 297.368 units from Kindergarten to High School. Meanwhile, the higher education addds to 4.504 units, though they are consitituted largely by private institutions. [1]

Currently, such educational institutions are less trusted, a condition proved by the minimum amount of student's enrollment. Several private schools, from the elementary, secondary, to higher education levels have difficulties when it comes to enroling new students, whereas in State Schools often have an overwhelming number of candidates of new students. The Educational Observer from Tanjungpura Pontianak University West Kalimantan, Dr. Aswandi, affirms that society's trust towards education is on a downward trend and may compromise the 
quality offered [2] Motivated by the afforementioned conditions, the writer wished to explore the concept of developing trust towards educational institutions, particularly the private ones.

\section{Study of the Theory}

Trust is the ability to rely on other people's words and actions [3]. According to Greenberg and Baron, trust is the belief in one's words and actions on others [4]. Similarly, George and Jones view trust as the willingness of one person or a group to have faith or confidence in the goodwill of others, even though this puts them at risk (because the other might act in a deceitful way) [5]. Trust on individuals or organizations is not based only on their words, but also on their actions. In the educational institutions are entrusted with promotion of school's planning program as well as its application.

Developing society's trust towards educational institutions is not something that can be done instantly. Trust is basically constructed based on procedurally. There are five elements upon which trust on one or institution can be build. DeJanasz, O Dowd and Schneider state that trust is composed of five elements ; integrity/honesty and sincerity, competence/knowledge and ability, consistency/conformity with previous practice, loyalty/faithfullness to ones friends and ideals, openness/not closed to new ideas, and willingness to share ideas with others [6].

Furthermore, Robbins and Coulter explain five dimensions that make up the concept of trust; integrity, competence, consistency, loyalty and openness [7]. Similarly, Robbins and Judge affirm that trust is a positive expectation that an individual will not- through words, actions, or decisions act opportunistically. Evidently, the following are the five dimensions of trust: (1) integrity, refers to honesty and truthfulness, (2) competence, which encompasses an individual's technical and interpersonal knowledge and skills, (3) consistency, relates to an individual's reliability, predictability, and good judgment in handling situations, (4) loyalty, which is the willingness to protect and save another person, and (5) openness, readiness to receive new ideas [5].

Trust towards educational institution can be perceived from two perspectives, that is, both internal and external sides of the institution. The trust from internal side involves the reliability of internal stakeholders towards the institution. For instance, the trust of teachers, students, as well as the entire staff towards the school. Meanwhile, the external trust encompass the dependability of the society, government, or other organizations towards the school.

A trust of organization member on his/her leader is absolutely needed to work maximally and actualize the vision of organization. McShane and Von Glinow affirm that employees identify with and feel obliged to work for an organization only if they trust its leaders [8]. on the other hand, developing a trust can be positively influenced by support, respect, justice, and competence [9].

A trust from external factors can be formed when the institution has its own characteristics, of which three dimensions are competence, character and benevolence [10]. The characteristics of one institution should be unique and be as differentiator from other similar institutions.

\section{Research Methodology}

The methodology of this study was mainly literature based. The discussion used descriptive analysis approach and data was collected through the analysis of comparisons between previous 
research results and related theories as well as other relevant sources. The dataset can be seen at https://osf.io/7y9tq/

\section{Result and Discussion}

\subsection{Developing a trust from a trust dimension}

From the preceding sections, trust is built upon five dimensions: integrity, competence, consistency, loyalty, and openness. With these five aspects, a school will be able to embody its vision and will surely be trusted by the society. Integrity is basically the similarity between words and actions, and the school with this quality carries out and actualizes the well-planned goals. School's integrity can be reflected by its vision accomplishment as well as its organized plan application. For a school to be trusted, the surrounding communities must display integrity.

Competence is a skill to do something. A competentt school is able to facilitate teaching and learning activities that meets the standards established. Its competence is created by its community's aptitude. The principal in a trusted school have high competence (managerial ability, social, personality, entrepreneurship, supervision). Teachers must also have competence (pedagogic, professional, personality, and social). similarly, educational staffs should display competence, and so should the supervisor. For teachers and other educational staffs, the aforementioned competencies have been stated in the Regulations Number 14 Year 2005.

Consistency is constancy or stability in words and actions. The consistency of an educational institution should be seen from academic approach by the community around. Within the institution, the focus should be on how it brings quality. School that consistently carries out its activities with quality-oriented approaches often gain the trust of the society. In addition, consistency in applying the related regulations is also important in gaining society's trust.

Loyalty involves a the steady adherence to someone or institution. The loyalty of educational institution is reflected in its academic community's approaches and genuineness. Teachers who are obedient to the principal and school's regulation are loyal. Similarly, the principal who administers his/her main duty and function based on Standard Operational Procedure (SOP) displays his/her loyalty. This aspect is also seen from school's adherence on the applicable regulation, such as fulfilling the eight education national standards.

The openness relates to transparency, a value schools can display through announcing or advertising their activities explicitly. The more open a school is, the more explicit the society understands the conditions surrounding it. The openness shows the responsibility that finally brings out trust.

\subsection{Developing a trust towards school based on the internal and external trust}

Developing a trust towards educational institution beginins with the internal transparency. When the internal parties do not trust school, it is impossible for the external ones to show conviction in it. The trust can be developed when all parties are satisfied with services rendered by the school.

Developing the stakeholder's trust (internal and external) is motivated by a powerful leadership. Furtasan Ali [11] proposes that leadership has direct influence on trust. A powerful leadership will be able to formulate vision and actualize it. A powerful leadership always wants to help and to empathize employees. 
In an organizations, the role of leader is very important. For instance, the principal plays a crucial role promoting the development of a school. The principal must be visionary, courageous, and able to make appropriate decision for the school.

A powerful leader establishes a good communication with members of the organization. George and Jones say that managers who helped their subordinates in the past and who interact with them are likely to enjoy high levels of trust among subordinates [5]. In addition, workers are more likely to cooperate with such supervisors than others. This communication skill is not only applicable inside but also outside the school.

The communication effectiveness at school and between school and outsiders determines society's trust. A less appropriate information with a good communication is more likely to be accepted by society. If the positive information is not well communicated, it can hardly be valuable. Syed Shah Alam and Norjaaya Mohd Yasin [12] and Shpetim Cerri and Aleksander Xhuvani [13] explain that communication has direct effects on trust.

A trusted school will always be a discussion-focus in the midst of the society. The communication from mouth to mouth is the best promotion media, as well as the effective way to build trust. When other parties feel the school can be trusted, the society is more likely to trust such news better than when conveyed by the internal stakeholders of the school. Ilyoo B. Hong and Hwihyung Cho [14] established mediator's trust has a significant role in determining consumer's satisfaction level and trust to the product of a seller.

A conducive school setting is also important since related parties can work comfortably. When the a conducive environment is formed, the cooperation among workers will be strongly linked. Shpetim Cerri, Aleksander Xhuvani [13] states that the quality of cooperation affects trust. Through a conducive setting, the negative information about the organization can be minimized. This cooperation will make other parties trust the establishment. Jessica Price-Jones established that trust in your organization flows from two sources: colleagues and senior leaders [15].

A conducive school's setting leads to attractive working conditions., something that may become a talk outside the school and positively influence society's trust on school. The principal and other key stakeholders must be able to create an appropriate working environment, including teaching and learning activities in the classes. The organizational culture affects public trust. School with a quality-culture will always implement activities through welloriented activities. The society supervising the school with a quality-culture will with no doubt trust it. From the research result of Dedi Sutan [16] and Furtasan Ali [11], organizational culture has a positive and a direct influence on the trust. A competent schoolin this regard is able to meet stakeholder's wants.

Organizational culture is formed mutually by all the members. School with various individual's backgrounds definitely has a different culture and can create a new habits which supports the community in achieving an optimum work performance. This effort can be implemented through regulations and applicable operational standard procedures at school. The personalities of individuals in school is also significant in forming the society's trust. Indonesian's society upholds noble values. The personalities of the principal, teachers, educational staff, and students determines society's trust towards the school. Dedi Sutan [16], Shpetim Cerri, Aleksander Xhuvani (2012) establshed that differences in personality affects trust.

Teacher's personality can be exemplified and modeled. The education context in Indonesia has well-known terms from Ki Hadjar Dewantara, such as Ing Ngarsa Sun Tulodo, Ing Madya Mangun Karsa and Tut Wuri Handayani. This means that someone must be able to be a good example, to be a proper supporter and a good initiator. 
Developing a society's trust towards the school can be also done if the school obeys the rules established. Shpetim Cerri and Aleksander Xhuvani propose that the rule of law affects trust. The requirements should be fulfilled not only as the administration issues but also as the obligation for school to accomplish them [13]. Such requirements incllude the minimum number of teachers and their qualifications, laboratorium minimum standard, educational staff standard, financial standard, and so forth.

Baljeet Kaur and Sushila Madan establisheed that one of the factors that influence consumers' trust is product description. In the educational context, product description can be said to be the competence obtained by students after finishing their learning course[17]. As the non-profit institution, this product description must also be seen from its application process. The competence generated by the school should be measured and have particular standards.

The competence obtained by the students should be acknowledged by the public. The society knows the school's existence with its students' particular competence characteristics. For instance, a school that has an entrepreneurship-based students' competence is likely to win the trust of the society.

\section{Conclusion}

From the discussion above, the following conclusions can be drawn:

a) Developing trust towards educational institution can be facilitated through such qualities as integrity, competence, consistency, loyalty, and openness.

b) Developing a trust should be based on both internal and external aspects including a powerful leadership, a conducive environment, an organizational culture, an effective communication, a strong personality, obedience on regulations and product description.

\section{References}

[1] Katadata.: Berapa jumlah perguruan tinggi di Indonesia," in Katadata.com, ed, 2018.

[2] Aswandi.: Masyarakat dikhawatirkan mulai kurang percaya pendidikan," in Antara Kalbar, ed, 2008.

[3] J. W. Newstrom.: Organizational Behavior Human Behavior at Work. New York: McGraw Hill, 2011.

[4] J. Greenberg and R. A.Baron.: Managing Behavior in Organization. New Jersey: Pearson, 2009.

[5] J. M. George and G. Jones.: Understanding and Managing Organizational Behavior: Delta Publishing, 2006.

[6] S. C. DeJanasz, K. O. Dowd, and B. Z. Schneider.: Interpersonal Skills in Organizations. Boston: McGraw Hill, 2009.

[7] S. Robbins and M. Coulter.: Management 13 ed. New York: McGraw Hill, 2014.

[8] S. L. McShane and M. A. VonGlinow.: Organizational Behavior. New York: McGraw Hill, 2010.

[9] R. Kretner and A. Kinicki.: Organizational Behavior. New York: McGraw Hill.

[10] Colquit, J. A. LePine, J. A. Wesson, and M. J.: Organizational Behavior Improving Performance and Commitment in the Workplace. Boston: McGraw Hill, 2009. 
[11] F. A. Yusuf.: The Impact of Organizational Culture, Leadership, Job Satisfaction and Trust toward Lectures Organizational Commitment of the Private Universities in Serang Regency Indonesia," International Journal of Human Resource Studies, vol. 7, 2017.

[12] S. S. Alam and N. M. Yasin.: What Factors Influence Online Brand Trust: Evidence From Online Tickets Buyers in Malaysia.: Journal of Theoretical and Applied Electronic Commerce Research vol. 5, p. 12, 2010.

[13] S. Cerri and A. Xhuvani.: Exploring Factor Affecting Trust and Relationship Quality in A Supplay Chain Context.: Journal of Business Studies Quarterly, vol. 4, p. 17, 2012.

[14] I. B. Hong and H. Cho.: The Impact of Consumer Trust on Attitudinal Loyalty and Purchase Intentions in B2C E-Marketplace : Intermediary Trust vs Seller Trust," International Journal of Information Management., vol. 31, 2011.

[15] J. Price-Jones.: Happiness at Work Maximing Your Psychological Capital Your Success: WileyBlacwell, 2010.

[16] D. S. Ardani.: Influence of Organizational Culture, Team Conductivity, Personality and Trust to the Leading Organization Commitment, International Journal of Human Capital Management, vol. 1, p. 9.

[17] B. Kaur and S. Madan.: Factors Influencing Trustin Online Shopping: An Indian Consumers Perspective, European Journal of Business and Management, vol. 5, p. 8, 2013. 